\title{
ethic@

\author{
CAN THE CONGENITAL ZIKA VIRUS SYNDROME CRISIS \\ CONTRIBUTE TO CHALLENGING CONTEMPORARY DISCOURSES \\ AGAINST ABORTION LEGALIZATION IN BRAZIL?
}

\author{
TAMARA AMOROS GONÇALVES E DANIELA ROSENDO ${ }^{1}$ \\ (University of Victoria, Canada/Universidade Federal de Santa Catarina, Brazil)
}

\begin{abstract}
In this paper we will explore the widespread of congenital Zika virus syndrome in Brazil associated with abyssal social inequalities as a trigger to push for abortion legalization from a human rights perspective. Brazil has a very restrictive regulation on abortion, which allows the procedure only when the life of the mother is in danger, in cases of pregnancy resulting from sexual violence, and when the fetus suffers from anencephaly. Due to the growing influence of ultra-conservative forces in the Parliament, the legislative debate on abortion has been blocked for many years in Brazil, making social movements seek the courts for advancements in this area. In this paper, we will present general data on the Zika epidemic, social inequalities and unequal access to health services as a background for the discussion on advancing abortion legalization in the country through judicial procedures, from a human rights perspective.
\end{abstract}

Key-words: Zika Virus Syndrome; Abortion; Legalization; Human Rights.

\section{Introduction}

Brazil is a society structured by patriarchy, sexism, and classism. This structure further exacerbates social inequalities, since under capitalism, patriarchy, sexism, and racism are combined to economical exploitation, preventing social justice. In recent years, the growth of ultraconservative moments have contributed to worsen this scenario. From a political and ethical standpoint, these conservative forces have been posing challenges to the recognition and implementation of human rights, in particular, women's sexual and reproductive rights.

A diverse and consistent feminist movement have been challenging this structure from multiple political orientations. Important advancements were accomplished on violence against women (challenges still remain) (PASINATO, 2016), but very little was achieved in terms of ensuring sexual and reproductive rights. Not only advancement in legalization and 
enforcement of the existing legal framework has been insufficient, but it also has been paralleled with a strong backlash affecting family planning, sexual education, and abortion. Recently, a real crusade against what conservatives have been calling "gender ideology" is at stake in Brazil. These conservative groups claim that "gender ideology" is responsible for dismantling families and must be fought. Therefore, guidelines on education have been restricted to avoid any discussion related to gender and even bill proposals to forbid such discussions are being presented at the Congress (FUNDAÇÃO PERSEU ABRAMO, 2016).

Being illegal, it is hard to precisely quantify the number of unsafe abortions performed in Brazil. In 2013, the estimated number of induced abortions in Brazil among women aged 14 to 49 years-old was between 687,347 (lower limit) and 865,160 (upper limit). Comparing to 1991 , when it was estimated between 300,000 and 3,3 million illegal abortions performed each year, and in 1994, when the Alan Guttmacher Institute more precisely estimated an annual rate of 36.5 induced abortions per 1,000 of women aged 16 to 49 , recent data shows a decrease of $26 \%$ of induced abortion. However, despite this reduction, the magnitude of abortion is Brazil still remains a serious public health problem, especially due to its relation to maternal mortality (MONTEIRO, ADESSE and DREZET, 2015).

A national-wide research conducted in Brazil pointed out that by the age of 40 years old, one in five Brazilian women has had an abortion. The same research showed that in 2015 there were half a million abortions in Brazil (DINIZ, MEDEIROS and MADEIRO, 2017). For the cases where abortion is legal, women have a hard time accessing the public services. One of the main reasons is the absence of clinics providing such procedures. The number of clinics and hospitals legally offering abortion have been shrinking over time and even if Brazil has more than 5 thousand cities, only 37 clinics are offering legal abortions (INSTITUTO PATRICIA GALVÃO, 2015).

On February 2016, World Health Organization (WHO) declared Zika virus an epidemic public health emergency based on evidences from Brazil connecting microcephaly and other neurological disorders related to Zika infection. On November of the same year, WHO (2016) declared the end of the Public Health Emergency of International Concern. Nonetheless, the epidemic alarm in 2016 induced fast international action, combined with intense coordination between countries, in particular in Latin America, led to a consistent (but not satisfying) response to the crisis. The fact that the international emergency call was reviewed does not signal the problem is solved or close to be solved. By the contrary, new affected areas have been identified: from 2015 to February 2017, the number of countries 
reporting Zika reached 59, with a major concentration on South and North America, but also spreading to Africa and other continents. In March 2017, 84 countries, territories or subnational areas had evidence of Zika transmission (WHO, 2017). Worldwide, 3.000 cases of Zika-related microcephaly or other central nervous system (CNS) malformations were identified, 2.366 babies born in Brazil (THE LANCET, 2017).

Zika virus was first identified in 1947, in Africa. In 1953, human illness caused by Zika was first confirmed in Nigeria. In 2007 an outbreak of the disease was find on several islands in the State of Yap (Federated States of Micronesia), resulting in around 5.000 infections among a population of 6700, reporting mostly a mild febrile illness. In 2013 and 2014, the outbreak took place in French Polynesia, supposedly involving 32,000 persons. At this point, however, although the febrile condition was present, cases of Guillain-Barre Syndrome were also noted. In March 2015, the virus was first identified in Americas, in the state of Bahia, Northeast of Brazil. By September 2015, investigations noted an increase in the number of infants born with microcephaly in the same areas where Zika was identified and by mid-February 2016 more than 4,300 cases of microcephaly were reported in Brazil (PETERSON et al, 2016). On November 2015, the Brazilian Federal government declared a national public health emergency (BRASIL, 2015). In August 2016, there were 8,890 cases of microcephaly or other CNS notified to the Ministry of Health (MINISTÉRIO DA SAÚDE, 2016b). Since February 2016, notification of Zika virus infection became mandatory in Brazil (MINISTÉRIO DA SAÚDE, 2016c).

Even if further research is still being done, medical literature published so far recognizes the connections between Zika virus infection, caused by a mosquito bite (Aedes Aegypti), in particular when affecting women during the first trimester of pregnancy, and microcephaly in fetuses and babies. Early fetal loss and fetal death is also associated with maternal infection by Zika virus. ${ }^{2}$

Brazilian weather presents a good environment for the mosquito reproduction and this, aligned with the critical infra-structure problems (lack of sewage, garbage collection and so on) favors epidemic crisis caused by the mosquito, like Zika and Dengue. In Brazil, Zika virus and microcephaly cases have been having prevalence in the Center-East and Northeast regions of Brazil, which accounts for of 270.1 and 172.1 cases per 100 thousand habitants respectively. Discussions in the literature have been linking a higher risk of microcephaly and other congenital malformations linked to Zika geographical location (JAENISCH et at, 2017). 
The cases of fever related to Zika are more common amongst women in reproductive age (20 to 49 years old) representing $59.6 \%$ of cases (78,795 cases). Official data does not always consider race/ethnicity, but when this information was available, the infection was more common amongst brown women ("parda") with 45,423 cases reported (58.6\%), 25,598 in women in fertile age and 7,042 in pregnant women. Women affected are also the ones with lowest levels of education. Even if this data was not collected consistently, when it was registered, it indicated high school (completed or incomplete) was predominant amongst women in the reproductive ages (41.8\%) and pregnant (47.8\%) (MINISTÉRIO DA SAÚDE, 2016a). By the end of 2016, Brazil has confirmed 1,845 cases of Congenital Zika syndrome in babies, while there were 9,091 suspected cases (DINIZ, MEDEIROS and MADEIRO, 2017).

In this context, Zika's epidemic affects disproportionately women from unprivileged classes: they are the ones that live in the most precarious conditions, without or very poorly organized sewage collection and treatment, running water or garbage collection, in short, without minimal infra-structure conditions. Very often, the lack of garbage collection by the municipality or the unavailability of piped water supplies transforms people's houses in fertile focus for the reproduction of the mosquito. If in conditions of environmental problems and extreme poverty women are already disproportionately affected (ROSENDO, 2015), this is aggravated in contexts where sexual and reproductive rights are not fully (or even minimally) ensured.

The Zika epidemic and its link to microcephaly and other neurological consequences has brought abortion legalization to the center of the debate in Brazil. In August $24^{\text {th }}$ 2016, the National Association of Public Lawyers (ANADEP - Associação Nacional de Defensores Públicos), supported by a non-profit organization, ANIS - Instituto de Bioética proposed a collective lawsuit before the Supreme Court in Brazil requesting that: i) financial support for the mothers of babies with microcephaly and for the babies themselves; ii) the federal government ensures proper medical attention to families with babies with microcephaly (within $50 \mathrm{~km}$ of distance); iii) the federal government provides complete information to all women and teenagers in reproductive age about how to prevent Zika virus, also making available information and contraceptive methods in all health public units; iv) the Supreme Court amplifies the legal exemptions regarding abortion already existing in the Criminal Code (articles 124, 126 and 128), to encompass cases of microcephaly. The latter request means that abortion in those cases would not be criminalized. 
Considering the magnitude of unsafe abortion in Brazil and connections between Zika virus and microcephaly, our aim in this paper is to better understand if Zika virus epidemic can be a window of opportunities to overcome social resistance against legalizing abortion in Brazil, considering how social inequalities, including unequal access to health services is related to an also unequal enforcement of the law that criminalizes. We presuppose an ethical background that considers situations when abortion is morally permissible, moving away from a conservative point of view and moving forward a human rights paradigm permeated by a gender and feminist lens. We will offer an insight on the Brazilian political scenario, investigating possible political outcomes related to the Zika virus epidemic and the protection of women's sexual and reproductive health, dignity and autonomy more broadly. Through these perspective, access to health care, including services that promote and ensure sexual and reproductive rights should be understood as a fundamental human right.

\section{The Legal Landscape: International, Constitutional, Criminal and Civil perspectives}

Even in secularized States, reproduction and sexuality are not only a matter of civil law, it can also be a subject addressed by criminal law. This occurs in Brazil and in other countries as well. Criminal law is known as the ultima ratio, which means that criminal law is the last resource to regulate human behavior, applicable when all other social and legal controls fail (MINKKINEN, 2006). In general, the most precious social values tend to be protected by criminal law, like the right to life, privacy or property. Criminal law is a more severe way to regulate relationships within society, as it deals with restraining fundamental rights, like freedom. Criminal law can protect sexuality and reproduction when it imposes sanctions to sexual assaults/sexual violence or when it condemns forced sterilization, for example. At the same time, criminal law can operate as a form of control over feminine bodies and reproductive choices, when it criminalizes abortion for example. So, at once, criminal law can protect and limit women's sexual and reproductive life and women can be rendered a criminal or a victim.

In democratic societies, human rights principles are the foundation of legal regulations. These principles are set by a constitutional design or through the incorporation of human rights international treaties. Laws on reproduction and sexuality under a human rights framework are quite recent, as it is recent the process of consolidation of a contemporary human rights paradigm - after the Second World War - that also encompasses a gender perspective (GONÇALVES, 2013). In Brazil, it was not different. The 1988 Constitution 
(approved after the end of Military dictatorship in 1984) sets right in the firsts articles that the Brazilian State is guided by the prevalence of human rights and protects human dignity as one of the foundations of the Republic. The Constitution also establishes the incorporation of human rights treaties as additional protection for citizens (PIOVESAN, 2006). Despite the Constitutional provision, infra-constitutional laws are not always in tune with these parameters, such as the Brazilian Criminal Code.

The Decree-Law no. 2,848 (Criminal Code), from 1940 and still in force today, reflects the bias and prejudices of its own time: it specified sexual crimes as "crimes against the honor", whose victims were only "decent women" (provision only changed by Law no. 12,015 in 2009). Regarding abortion, its practice is allowed only in two situations: when the pregnancy resulted from sexual violence or when the life of the woman is in danger. In 1940, these rulings could be considered advanced in comparison with some Western European countries. But during the 1970s, Western European and North American countries, in the context of intense social transformations and due to second wave feminist pressures legalized elective abortion and Brazil stood behind. In those countries, the legal changes intended to promote women's equality within the family and work place. Legal abortion was comprised of these social and legal changes, being supported by the two main social discourses of the time: the liberal and socialist (DUDOVÁ, 2010). For the first ones, legal abortion was a matter of personal choice and individual freedom and for the latter, legal abortion was essential to ensure equal work conditions.

Liberal and socialist discourses in Brazil did not encompass the legalization of abortion. At least two Brazilian particularities influenced this context preventing legalization of abortion: i) the experience of the dictatorship and ii) the deeply grounded Catholic culture in the country. As to the first one, the link with abortion is less obvious but there is research pointing out at this connection (HTUN, 2003). The military dictatorship prevented Brazil from engaging in the cultural and political changes that happened worldwide during the 1960s, 1970s and 1980s. By the end of the dictatorship, conservative alliances that advocate "pro-life" policies were far better organized to block legal changes, as they have learned with the experiences from North American and European countries that have gone through legalization. Also, the military imposed severe violence upon Brazilian society, by massive torture, forced detentions and disappearances; which created an environment for advocacy to stronger protection of human life. By the end of this regime, social movements concentrated 
in ensuring a new constitutional order by building coalitions and avoiding controversial topics, such as abortion.

The military dictatorship, allied to conservative and religious forces, also meant the reinforcement of a traditional heterosexual paradigm for families, with a male breadwinner and a female housekeeper reflecting supposedly "natural differences" between men and women (BLAY, 2014). This also included the idea of maternity as a "natural" and a central role for women, through the reinforcement of the "essentialist difference feminism" doctrine proposed by Catholic religious tradition (HTUN, 2003). This doctrine and perception of the social role of women are not exclusive to the Catholic Church but is shared by the Christian community more generally. More recently, Brazil has seen the politicization of subjects related to LGBTT rights, sexual and reproductive rights in general and abortion in particular due to an increasing polarization of these debates with conservative groups, mostly aligned with Christian community and Neo-Evangelicals. A lot of the resistance in changing laws regarding abortion in Brazil are credited to a "conservative activism", pushed by religious groups in the Congress (MACHADO, 2014). In Brazil, these conservative groups are also aligned with powerful economic forces, such as representatives of neo-pentecostal groups, agribusiness, and gun manufacturers in what has been called the BBB Coalition (Bancada da Bala, Boi e Bíblia - Bullet, Ox and Bible Coalition). These groups tend to back each other's interests and act coordinately.

Especially after the United Nations international conferences on population in 1994 (Cairo) and about women in 1995 (Beijing), religious conservatives have been reframing their discourses about sexual and reproductive rights, using the language of rights and public policies to sustain anti-abortion campaigns. For example, this sector has been arguing that abortion is a public health issue regarding the traumatic psychologic consequences it causes in women and that these women should be treated by the public health system and receive economic support that could prevent them of reaching out for abortion. The arguments are not anchored in express religious arguments, but are presented as bioethics and scientific evidence. Therefore, protecting family and life are framed as non-religious. To support this perspective, these groups very often ground their claims in international human rights treaties, such as the UN Convention on the Rights of the Child and the American Convention on Human Rights. Their conservative arguments do not point out to the differences between a fetus under development and an already born child. This results and reflects on a radical 
defense of the life of the fetus, leaving no room for debate, flexibility or different understandings or perspective regarding life and its protection (RUIBAL, 2014).

Brazil protects the right to life as a fundamental right constitutionally and by the incorporation of International Human Rights Treaties, such as the Inter-American Convention on Human Rights. But this protection is not considered absolute: when in confrontation with other fundamental rights, interpretation is required. Being such a fundamental right, it tends to prevail when conflicting with other rights. However, strictly considering the criminal framework, offenses to the right to life are punished differently. There is a gradation in the intensity of the punishments determined by the Criminal Code regarding this subject: punishment in cases of abortion (considered by Law a crime against the right to life of the fetus) varies from one to three years of detention and in responsible for supporting case of homicides from 6 to 30 years. In cases of infanticide, the detention can vary from 2 to 6 years.

As the severity of the punishment varies, it indicates different protections for the right to life considering life's multiple stages. Therefore, fetus's lives receive less protection than a child's life. This renders clear that the right to life is not absolute and that different stages of life ensure different levels of protection. This idea will be important to discuss the conflict of the women's and fetus's right to life. As to the civil law, it protects the life of the fetus with an expected right of personality. This means that the law protects the fetus expected rights, which will be concretized once it is born alive. It is a protection for an expectative of rights; different from the protections around the woman's life, who is already born and therefore entitled and being able to exercise other rights.

A recurrent strategy from conservative groups have been to argue that the zygote contains all the genetic material, constituting a human being. This argument ignores that an individualized genetic material does not necessarily ensures the existence of a human being, with autonomous extra-uterine life. It is still a moral position, presented as absolute and leaving very little room for debate and different positions. Also, these religious-oriented group tend to use their ability to influence the State outside the public arena of debate, which leaves the society in a lack of public debate on this matter (RUIBAL, 2014).

On the local ground, then, both social groups (feminists and religious-conservatives) invoke human rights to support their discourses. The debate, therefore, goes beyond law. It is, in fact, a political and philosophical issue. In a feminist perspective, it is noticeable how the life of the fetus is framed as ample and potential, when the same ground is not acknowledged 
to the women. Very often, in the religious-conservative discourses the woman is considered as a mean to the existence of the fetus, but the life and autonomy of the woman herself is not taken into account. This reflects a sexist and misogynous perspective on philosophy, politics and even religion (TIBURI, 2014).

In short conclusion, we would like to bring into the discussion the inequality between women's rights and the fetus' rights. Specifically, we want to argue that giving human status to an unborn being, considering both as entitled to the same fundamental rights, is a strategy pushed by conservatives to block the debate (ROSENDO and GONÇALVES, 2015). Further, it considers both parties as equals despite completely different situations and conditions of being. While the woman is a human being, born and entitled to human dignity, the fetus counts only on the potentiality of this human dignity. Just after being born alive a person can be considered as a citizen subjected to equal rights in a given community and claim for her dignity (HABERMAS, 2010). The Brazilian law already consider women as subjects of rights, while the fetus has only an expectative of becoming one. Therefore, if a woman is forced to maintain the pregnancy, in this process the fetus becomes the "end" and the woman becomes only a "means". In this case, she is deprived of the condition of "subject" and is only an object, violating the Kantian principle of human dignity (TIBURI, 2014).

We believe that abortion must be a right of every woman who desires not to keep an unwanted pregnancy, regardless of the reason. However, due to the conservative wave in Brazilian society, which is reflected in laws and public policies, these rights have been violated, especially for black and poor women, because women that have financial resources do abort without been subjected to the criminal law (GRUPO DE PESQUISA...; IPAS BRASIL, 2012). Feminists have been seeking for strategies that may guarantee this right, regardless of social conditions and it is in this context that we are investigating how the Zika virus epidemic may contribute to that.

\section{Abortion, social inequalities and unequal access to health services at a conservative scenario}

The relationship between abortion and its illegality has to be considered within a social inequality framework. In Brazil, data shows that, in general, women access more health services than men. This information should be contextualized by other relevant data, regarding social class and other characteristics that might influence access to these services, 
like race and geographical location, for example. Women from upper classes and white are more likely to access health services, for both prevention and treatment of current disease (SENICATO and BARROS, 2012).

Although access to prenatal services are practically universalized, the quality of the health services provided still requires improvement: only $60 \%$ of women started prenatal care around the $12^{\text {th }}$ week and less than $10 \%$ did routine exams and received information about the delivery and breastfeeding, for example. Social inequalities among women were pointed as a central reason for the disparity in the quality of the health services, with indigenous and black women, together with the ones with less literacy, living in the North and North-east of Brazil receiving the less qualified services (VIELLAS et al, 2014).

Inequity in health care provision and access further exacerbate these inequalities, so it is not surprising that women living in poorer areas face more obstacles in accessing health services and preventing problems during pregnancy such as anencephaly and microcephaly. Health services in Brazil are divided into public and private ones. The public health system is based on national guidelines, implemented locally by the state and municipal authorities. Regional inequalities (north and south, urban and rural) contribute to the highly unequal quality of the services made available to the citizens. Big urban centers like São Paulo concentrate better health care options, both public and private, while far Northern cities rely on very precarious services.

As to the private services, they tend to offer better health care (CESAR et al, 2012), but lack of regulation and accountability leave citizens with problematic services, obtained many times only through judicial decisions that impose enforcement of contractual conditions or annulation of illegal clauses. Data from 2003 shows that around 43.2 million people in Brazil had any kind of private health insurance (counts for $24,6 \%$ of Brazilian population) (TRETTEL, 2009). In prenatal care and maternal care, the country faces many challenges, being one of the countries with the highest rates of caesareans (FAÚNDES and CECATTI, 1991) and high mortality associated with inadequate pregnancy care - have been held responsible by the CEDAW Committee ${ }^{3}$ by the deficient health care offered to pregnant women in Brazil.

White and high-income women tend to have better access to health care attention in general and better chances to afford an illegal but safe abortion procedure. It is not surprising, then, that criminal rulings on abortion tend to selectively affect poor women, which have more chances of performing unsafe abortions and end up in the public health system to treat 
hemorrhages and other complications related to the procedure (GRUPO DE PESQUISA...; IPAS BRASIL, 2012). Recently, the Zika epidemic crisis in Brazil have contributed to aggravating such inequalities.

The epidemiology of Zika, like abortion laws, disproportionately affects low-income women. Amongst the babies born with signs of congenital Zika syndrome, $60 \%$ were born from low-income women from Pernambuco, Bahia, and Paraíba (states in the North-east of Brazil) (MINISTÉRIO DA SAÚDE, 2016b).

In 2016, according to the latest report from the Ministry of Health, 215,319 cases of fever related to Zika were registered in Brazil, 8 deaths being confirmed by laboratory analysis. In 2017, 1,653 probable cases were registered. In 2017, 286 pregnant women infected by Zika virus were identified, 30 confirmed by laboratorial analysis.

The majority of cases tend to be concentrated in areas with low infrastructure, no running water, and no sewage or garbage collection: "Some 35 million Brazilians have no running water, over 100 million have no access to sewage, and more than 8 million city dwellers live in areas that lack regular garbage services, according to the most recent census in 2010.” (BROOKS, 2016)

It can be said, then, that women in Brazil, depending on their class and color might inhabit very different worlds: while some live in developed societies with full access to basic social infrastructure, medical care and participate fully in the consumer society - living then, in an affluent society (MARCUSE, 2005) -; others are denied the very basic minimal conditions to exist - they live in underdeveloped societies. The particularity here is that these two societies coexist and sometimes are separated only by a street.

The social group that merely survives do not manage to change the intolerable conditions of existence they inhabit - by lack of political power, voice and because the life conditions barely sustain an existence (SOUZA, 2016). They suffer disproportionately in relation to other women in many different ways: i) because they have less access to health services and fewer possibilities to prevent or even plan pregnancies; ii) when they decide to undergo an abortion, they are exposed to more severe risks because they cannot pay for illegal but safe procedures; iii) they are more exposed to Zika virus and other health problems that might affect pregnancy; iv) when giving birth with babies with microcephaly or other diseases, they, in general, do not have all the resources to support the children needs; and 
finally, v) they have higher chances to suffer from health problems, die or face criminal charges for doing illegal abortions.

When the Zika epidemic exploded, even being considered a social calamity and being transmitted by a mosquito, it affected mostly the more vulnerable social groups. Multiple campaigns have been promoted to exterminate the mosquito by governments in the three levels (federal, state and municipal), with inspections being made especially in the poorest areas (the privileged focus for the mosquito reproduction). Although these campaigns seem essential, without addressing the structural problems, the transmission of diseases tends to continue and be transformed (dengue, Zika and so on).

Even if WHO (2016) revoked the Public Health Emergency of International Concern, issues remain due to two main factors: i) the expansion of the Zika infection around the globe, not only through mosquito bites but also through sexual contact; ii) the long-term effects related to the neurologic malformation and its long-term effects. If Zika virus affects disproportionately marginalized and poor women, they are the ones less likely to obtain the adequate support to endure the consequences of such neurological malformations. In short, the Zika infection aggravates the vulnerability of the already extreme vulnerable women in Brazil. This means that more and comprehensive options have to be in place for women in these situations, including, but not limited to: the possibility to have a legal and safe abortion; and the possibility to carry the affected baby to term, with public services and support, including financial, medical and developmental support to raise these babies.

During the peak of the crisis, on February 2016, United Nations High Commissioner for Human Rights (UNITED NATIONS, 2016) urged countries with restrictive laws to make abortion legal when the mother is infected, particularly in Latin America and in other areas affected by the epidemic.

In Brazil, the legalization of abortion has been part of the feminist movement's agenda for a long time. In the recent history, the topic was more highly debated in at least four situations: i) when in 2004 a collective action seeking to allow abortion in cases of anencephaly was proposed before the Supreme Court and when it reached a final decision in 2012; ii) during the presidential campaign in 2010; iii) in 2016 with the Zika virus crisis; iv) in 2018 during the public hearing of the ADPF 442, a collective action seeking to decriminalize abortion until the $12^{\text {th }}$ week of pregnancy ${ }^{4}$. 
Legalizing abortion is a historical claim and it is part of the demands formalized in all public conferences to discuss public policies for women. It is interesting to note that although discussions about legalizing abortion were present in the reports from the second and third national conferences, this agenda was not reflected on the National Plans that were consolidated by the federal government. ${ }^{5}$ Despite this, due to conservative alliances within the National Congress, law proposals have been passed in the Chamber of Deputies that aims to withdraw the rights already conquered by women, especially regarding sexual and reproductive rights. In 2015, a law that aimed to make legal abortion even harder to access (INSTITUTO PATRÍCIA GALVÃO, 2015) and to forbid the distribution of emergency contraception was approved by the Lower Chamber of the Congress. By that time, thousands of Brazilian women went out on the streets to protest against these proposals and claim for the president of the Deputies Chamber to be changed. This intense feminist activism, both on the streets and in social media can be seen as a window of opportunities to strengthen women's rights, even in such an adverse context.

Medical authorities have been advising women living in areas affected by the epidemic to avoid or delay pregnancy as a way to prevent (COLLUCCI, 2015) microcephaly (WENTZEL, 2015). On a research performed by Diniz, Medeiros and Madeiro in 2016, the authors founded that women are actually doing this:

A large proportion (56\%) of women reported that they had avoided (or tried to avoid) pregnancy because of the Zika epidemic. In contrast, $27 \%$ of women reported that they had not tried to avoid pregnancy because of the Zika epidemic and 16\% reported that they had not been planning to get pregnant, regardless of the Zika epidemic. A higher proportion of Northeastern women (66\%) than Southern women (46\%) reported trying to avoid pregnancy - which likely reflects the fact that epidemic has been more concentrated in Northeastern Brazil. There were no significant differences among the main religious groups: $58 \%$ of Catholic women and $55 \%$ of Evangelic women reported having avoided pregnancy because of the Zika epidemic. Black (64\%) and Brown (56\%) women were more likely to report avoiding pregnancy than White women (51\%), which also likely reflects the disproportionate impact of the epidemic among the most vulnerable racial groups (DINIZ, MEDEIROS and MADEIRO, 2017).

This is a real challenge in a country with a deficient health system and that offers insufficient sexual and reproductive health assistance. It is also a way to reinforce existing 
social inequalities, as women in the most affected areas are the ones with less access to the health services and contraception options/advise. This is precisely why the authors of the mentioned research strongly recommend that the Brazilian government must re-evaluate its reproductive health policies, including the criminalization of abortion (DINIZ, MEDEIROS and MADEIRO, 2017). Either way, conservative reactions have also been intensified and adjusted this guideline to the Catholic Church's conception of contraception: Brazilian Bishop Conference strongly opposed to abortion and has been asking women to delay pregnancy by practicing abstinence.

\section{Human Dignity and International Human Rights Law as a paradigm for reasoning abortion laws and policies in Brazil}

The emphasis on human rights as a historical process contributes to unveil the power struggles that preceded the recognition of something as a human right. In this context, the supposedly neutral language of human rights tended to rend invisible important social groups, which were excluded from the universalism propagated by the internationalization of human rights during the Post Second World War. Feminist groups challenged this supposed neutrality, also claiming that the law plays a significant role in upholding a particular asymmetric relationship between men and women. This supposed neutral language omitted any perspective that differed from the white western male perspective. Pushed by the activism of feminist groups and scholars, debates about the specification of human rights took place internationally and were reflected not only in Conventions and Declarations but also in national constitutions.

Feminist scholars such as Binnion (1995) and Mackinnon (2001) stressed that the human rights agenda would have been different if women and women's needs were taken into account as the process of formulation of human rights unfolded. Women tend to face human rights violation in the private sphere; while the idea of human rights was mostly developed as a protection against violence perpetrated by States. This is not to say that women are not subjected to the same kind of rights violations as men; but instead, to stress that women suffer additional human rights violations related to the particular condition of being a woman and to what means to be a woman in specific cultural contexts. These specific violations are very often related to sexuality and reproduction and intimate private relationships and it is in this context that regulations on sexual and reproductive issues in a human rights framework gain importance. 
The consistent feminist advocacy before UN bodies has been important to bring a gender perspective to the human rights field stressing the need to address women's rights violations as human rights violations. Cairo (1994) and Beijing (1995) Conferences and the international guidelines that resulted from these meetings are the most important documents to address sexual and reproductive rights as human rights. They not only discuss sexuality and reproduction but also explicitly urge States to deal with abortion from a feminist perspective. Although very important as references and guidelines, these documents are not legally binding, which means that States engaged during the discussions and that approved the declarations are not obliged to implement them. Still, they guide the interpretation of other human rights documents (conventions) and national legislations as well (PIOVESAN, 2007).

Two conventions (international and regional) deal specifically with women's rights: The International UN Convention on the Elimination of All Forms of Discrimination against Women and the Inter-American Convention on the Prevention, Punishment and Eradication of Violence against Women. Both were incorporated into the Brazilian legal system and are legally binding. The first brings general guidelines to prevent discrimination against women and promote women's rights while the second one focuses specifically on violence against women.

These documents bring general rules on gender equality and sexual and reproductive rights and no specific rule about abortion. However, every time Brazil submits its periodic follow-up report to the CEDAW Committee, the experts are unanimous in recommending Brazil to legalize abortion. This was the case in 2007 and in 2012 when the Concluding Observations of the CEDAW (2012) Committee to Brazil expressed concern with the bill proposals being discussed in the Congress that might contribute to restricting abortion even more. According to the Concluding observations of the Committee on the Elimination of Discrimination Against Women to the Brazilian Government, published in 2012:

The Committee urges the State party to:

Expedite the review of its legislation criminalizing abortion in order to remove punitive provisions imposed on women, as previously recommended by the Committee (CEDAW/C/BRA/CO/6, para. 3); and collaborate with all relevant actors in order to discuss and analyze the impact of the Estatuto do Nascituro in further restricting the existing narrow grounds for women to undergo legal abortions, before it is adopted by the National Congress; (CEDAW, 2012). 
The CEDAW recommendations to Brazil contributes to reinforcing the need to promote a gendered perspective to the concept of human rights, particularly on topics related to sexuality and reproduction, including abortion. They consolidate feminist claims into a concrete grammar of human rights to be adopted by State parties. They also reveal the importance to take into account individual's concrete experiences and rights violations when defining what can be considered as a human rights violation.

In 2011, another important treaty regarding women's rights was opened to signatures by the Council of Europe. The Convention on preventing and combating violence against women and domestic violence (also known as Istanbul Protocol), although approved by the Council of Europe, is open to non-Europeans countries. This is the first time a regional document is available for States from other regions to join. So far, only European countries ratified the convention, which entered into force in August 2014. This is a very comprehensive international framework on violence against women and deals specifically on the subject of abortion on article 39, determining State-parties should criminalize forced abortion and forced sterilization (COUNCIL OF EUROPE, 2011).

\section{Judicial alternatives to the blocked debate within the Congress}

Considering that abortion is only legal in Brazil when woman's life is in danger or the pregnancy results from sexual violence, women have been advised to seek judicial permission to undergo an abortion procedure in cases of fetus's malformations. In the case of anencephaly, a collective action presented to the Supreme Court was able to broad the cases of legal abortion in Brazil. Strategic litigation has been used by feminists and other social movements when the debate seems blocked or denied in other spheres, such as the legislative.

In cases of anencephaly, single judges and then state courts started to receive more and more cases where women requested permission to have an abortion in these situations. Some courts decided favorably to the women, some denied the right to abortion, which caused legal insecurity on whether it was legal or not to do an abortion in such cases. In many occasions, permissions for abortions were presented in regional news and priests started to interfere by presenting habeas corpus in the name of the fetus. In many cases, judges decided favorable to the fetus "fundamental right to life". In others, they declared that this is a medical issue and further information was necessary to make a decision. Or the court decision took so long to be made that, when it happened, the baby had already been born and died. 
Alongside the debate in Brazil, an important precedent from Peru contributed to affirm women's right to interrupt a pregnancy in cases of anencephaly. CEDAW had previously set a favorable precedent in this regard, in the case K.L. vs. Peru, submitted to the CEDAW Committee in 2009 by the Center for Reproductive Rights. The CEDAW's final decision stressed that obliging a woman to keep a pregnancy when she knows the fetus has no chance to survive can be considered a form of torture (CENTER FOR REPRODUCTIVE RIGHTS, 2002). Even if this was a case against Peru, it stands as an important legal reference to the Brazilian scenario.

This debate pushed organizations (partnership between Anis and the Federal Confederacy of Health Professionals) mobilization, which resulted in a collective lawsuit proposed before the Supreme Court to ensure women's right to abortion in cases of anencephaly. The Supreme Court took 8 years to make a decision on this case and judges finally ruled in favor of women in 2012, allowing abortion in cases of anencephaly, if this is the woman's choice. The argument of torture was also used by the judges to rule the case. After that decision, legal abortion, then, encompasses three situations in Brazil: when the life of the pregnant is in danger, when the pregnancy results from sexual violence or when the fetus has anencephaly. In 2014 the Brazilian Ministry of Health (MINISTÉRIO DA SAÚDE, 2014) published the national guidelines for abortion in case of anencephaly, which does not mean that women on the ground are having access to this service, since the number of clinics offering legal abortions in Brazil are very limited and concentrated in urban areas.

In 2016, ANADEP, supported by Anis, proposed another collective lawsuit before the Supreme Court aiming to ensure support for pregnant women affected by Zika virus, providing health, educational and economic support to raise the children with neurologic malformations and also to allow women to opt for abortions in cases of confirmed microcephaly (SENRA, 2016).

The anencephaly case took eight years to be decided by the Supreme Court and as the fetus did not have any kind of extra uterine life expectancy, the terminology abortion was avoided. The soften of the language - using "voluntary anticipation of childbirth" instead of abortion - seem to have been key in the success of this case. As to the moderation, the feminists reinforced throughout all the process that if the Supreme Court decision was positive, women would be able to choose end the pregnancy. This stood out as a more accommodating position than the absolutism of the position taken by religious conservative groups. 
Although there is not enough information on the development of children with microcephaly, what is known is that this development is problematic due to the multiple neurological problems related to microcephaly and CNS. The long-term effects of these conditions are still to be studied, but what is known for sure is that women, in particularly the most economic vulnerable, will probably face serious challenges in raising this child. Conservative groups are already questioning the lawsuit proposed by ANANDEP by pointing abortion in cases of microcephaly as an eugenic practice. However, the lawsuit has a broader scope, pushing for State's responsibility and support of women who had babies with microcephaly or Zika associated CNS and also requesting that abortion procedures done by request of pregnant women affected by Zika virus are not criminalized. As such, the action reinforces that legalizing abortion is a way to ensure women's sexual and reproductive rights as well as the right to autonomy in deciding whether and how to become a mother, regardless of the conditions of the fetus.

The question that remains is if it will be possible to overcome the blocked debate about abortion and obtain a positive decision also in the case of Zika virus, as was it done in the anencephaly one. The seek for a solution through the Supreme Court can ensure a more rational debate than the ones deliberated in the Congress, as the decision will be made through a judicial procedure, which supposedly requires a legal reasoning to be made. It is not to say that the Supreme Court is not sensitive to political tensions, but the impact of these pressures can be less intense in a context where the perspective to run elections is not on the horizon. This can be an improvement in terms of qualifying the debate about abortion in Brazil, even if the eventual positive decision does not resolve problems currently faced by Brazilian women by the lack of adequate sexual and reproductive health care, including abortion, as previously mentioned. At the same time, there is a conceptual risk in this movement, either by focusing too much on medical issues and on the fetus conditions, rather than on the rights of the women. Finally, a positive decision by the Supreme Court does not automatically translate into access to legal abortion on the ground.

\section{Concluding remarks}

Over the last sections, we have seen how social inequalities affect access to health services in Brazil and how criminal legal provisions on abortion affect differently women from upper and lower classes. Poor women in Brazil tend to have a less consistent access to health services, therefore also have limited access to contraception. When facing an 
unexpected pregnancy, women from all social classes seek illegal abortions, but the ones with higher incomes have better chances to find safe services. As a consequence, poor women are more likely to be charged by the criminal system for performing an abortion. When it comes to health problems related to the fetus development, poor women are also more likely to be affected, as in the case of anencephaly and microcephaly, enhancing vulnerability.

Due to the conservative wave, chances of changing the law in the Congress are very remote, so social movements have been turning to the Supreme Court on potentially polemic subjects, like abortion. The question that remains is whether discussing abortion in connection with microcephaly can help push forward a broader discussion on abortion in general and promote more gender and social equality in Brazilian society.

Radical discourses on woman's autonomy, not always balanced with the right of the fetus, face strong rejection in a society structured by religious and conservative values. Therefore, Brazilian feminist movements have been trying to promote abortion legalization by stressing the need to promote women's sexual and reproductive health, aligned with the international human rights discourse on the subject (RUIBAL, 2014). But even with extensive data and consistent advocacy by feminist groups, this discourse does not reach mainstream media. It also faces a strong resistance from religious and conservative groups. It seems that discourses that try to legalize abortion based on the protection of sexual and reproductive health do not overcome the moral and religious discourses that block any kind of initiative to legalize abortion.

Proposals like the one carried out in Uruguay seem not to be prosperous in Brazil, where bill proposals are increasingly pushing criminalization reforms to revoke the actual rights regarding abortion in Brazil. Also, sexual and reproductive health care services seem not to adequately promote family planning. This might also be connected to the lack of sexual education in schools, another agenda pushed by feminists, LGBTT, and human rights activists and blocked by religious groups.

Considering the blocked debate on legalizing abortion, due to the ultraconservative Parliament, social movements have turned to Courts to discuss controversial issues like abortion and same-sex marriage. Risks associated with discussing abortion in specific cases like anencephaly or microcephaly consists in narrowing down the focus of debate. By twisting the debate on whether abortion should be legal according to the conditions of the fetus, we run the risk of keeping the focus of the debate on the fetus instead of the woman's choices, rights, 
and autonomy. The legal debate proposed before the Supreme Court seems broader, but appropriations and debates by the general media and in society more generally not always encompasses the needed depth and complexity of the debate.

Even if feminists try to frame de debates arguing on the unequal and huge impacts of motherhood in women's lives as a central question of the debate, discussing the fetus's conditions to allow abortion might lead to undesired consequences, leaving the maternity issue more as a peripheral debate; when it should be considered at the center of the debate (CHAMALLAS, 2003). This contributes to maintaining the gender stereotypes associated with motherhood untouched or at least hidden. It also conceals too much power to the medical discourse, once that the decision will be made accordingly to what was reported by a physician. In other words, the power to make choice possible is in the hands of the medical class, not the woman herself. At the same time, it can be the first steps in amplifying the possibilities of legal abortion and avoiding a more intense debate on the moral level, by supporting the discussion on a supposedly more "neutral" discourse associated with medicine.

In the case of anencephaly, this detour was possible because there was no life expectancy after childbirth; the prognosis was death right after birth. In the case of microcephaly, even with the high rates of death, there is possibility of extra uterine life, but of a life full of restrictions related to the neurological damages caused in the brain, although some neo natal deaths associated with microcephaly have been reported. Also, anencephaly could be identified in earlier stages of the pregnancy; while so far microcephaly can only be identified around the $20^{\text {th }}$ week of pregnancy. This can also further complicate the public debate by both bringing in a discussion about eugenic abortion and about abortion after the $12^{\text {th }}$ week of pregnancy, which is not consensual within the medical class.

By the other hand, it may contribute to the right of the woman to choose to maintain or not a pregnancy, considering the risk of a late microcephaly diagnosis. It means, considering the risk of getting pregnant despite using contraceptive methods (neither one of them are $100 \%$ safe), there is a chance that a woman get pregnant and, in order to avoid the risk of having a baby with microcephaly, should have the right to decide whether to keep it or not. This decision should be made on the grounds of women's right to autonomy and the lack of solid information about the epidemic and consequences of getting pregnant.

Brazilian context puts in evidence a tension between what seems politically possible to obtain versus what it would be the ideal endeavored by feminist and "pro-choice" groups. On 
one side, the possibility to take the case to the Supreme Court might open a space that have been denied in the Congress; but it carries many risks in a moment where conservative groups have gaining strength in the public arena of debates. At the same time, a decision from the Supreme Court can take years to be reached and the Zika epidemic urges for action right now; and it would allow abortion just in those cases, not affecting all other cases where women are negatively affected by illegal abortion. Finally, even in those cases where abortion is legal, women encounter several difficulties in accessing health services (INSTITUTO PATRÍCIA GALVÃO, 2015).

The pernicious connections between illegal abortions, access to health care services and social inequalities in Brazil signal to the need to discuss legal abortion in a broader perspective, which can consider abortion as a component of sexual and reproductive health services. Abortion then should be encompassed on this health framework; health being considered as a fundamental human right. This is important to address the needs of women in different social classes, ensuring motherhood to be a choice, with State backing the women's choice to whether to be a mother or not. This means that the State should also be responsible to support women that decide to maintain the pregnancy even in adverse conditions, such as the ones related to deformations caused by Zika virus. The focus should then be on women's needs regarding motherhood, rather than the fetus perceived needs. 


\section{Notes}

1 Daniela Rosendo is a PhD. student in Philosophy at Universidade Federal de Santa Catarina (UFSC), Florianópolis, Brazil, and Teacher Associação Catarinense de Ensino/Faculdade Guilherme Guimbala (ACE/FGG), Joinville, Brazil. E-mail: daniela.rosendo84@gmail.com; Tamara Amoroso Gonçalves is a PhD. student at University of Victoria, Canada. E-mail: tamara.goncalves@gmail.com

${ }^{2}$ See: PETERSON, Lyle R. et al. Zika Virus. The New England Journal of Medicine, n. 374, p. 1552-1563, 2016. Available at <http:/www.nejm.org/doi/full/10.1056/NEJMra1602113\#t=article>; JAENISCH, Thomas et al. Risk of microcephaly after Zika vírus infection in Brazil, 2015 to 2016. Bull World Health Organ 2017, n. 95, p. 191-198. Available at: <http://dx.doi.org/10.2471/BLT.16.178608>.

${ }^{3}$ See the Case of Alyne da Silva Pimentel Teixeira ("Alyne") v. Brazil in the Inter-american Human Rights Systemof the Organization of American States (OAS).

${ }^{4}$ Althought we have pointed out to the ADPF 442, resembling its importance to the legalization of abortion in Brazil, we would like to call attention to the fact that the collective action was proposed only in 2017 , after the Zika vírus epidemic. Also, the present article was actually originally written before the public hearing mentioned. However, due to the importance of such hearing, we considered important to point out this moment.

${ }^{5}$ See: Anais da $3^{\text {a }}$ Conferência Nacional de Políticas para as Mulheres: Autonomia e Igualdade para as Mulheres, Brasília - DF, de 12 a 15 de dezembro de 2011, Available at $<$ http://www.spm.gov.br/assuntos/pnpm/publicacoes/anais-da-3a-conferencia $\geq ; \quad$ Anais da 2a Conferência Nacional de Políticas para as Mulheres, Brasília - DF, 17 a 20 de Agosto de 2001, Available at $<$ http://www.spm.gov.br/assuntos/pnpm/publicacoes/anais-da-2a-conferencia>; II Plano Nacional de Políticas para as Mulheres, Secretaria Especial de Políticas para as Mulheres, Brasília 2008, Available at $<$ http://www.spm.gov.br/assuntos/pnpm/livreto-mulher.pdf $>$; Plano Nacional de Políticas para as Mulheres 2013-2015, Secretaria de Políticas Públicas para as Mulheres, Brasília, 2013, Available at $<$ http://www.spm.gov.br/assuntos/pnpm/publicacoes/pnpm-2013-2015-em-22ago13.pdf. >. 


\section{References}

BINNION, Gayle. Human Rights: a Feminist Perspective. Human Rights Quarterly, v. 17, n. 3, Aug. 1995. Available at $<$ https://muse.jhu.edu/article/13489> Access on 21 Aug. 2017.

BLAY, Eva. Alterman. Feminismos e Masculinidades: novos caminhos para enfrentar a violência contra a mulher. São Paulo: Editora Cultura Acadêmica, 2014.

BRASIL. Governo aciona ações de emergência diante da alta de casos de microcefalia em PE. November 12, 2015. Available at: $<\underline{\text { http://www.brasil.gov.br/saude/2015/11/governo- }}$ aciona-acoes-de-emergencia-diante-de-alta-de-casos-de-microcefalia-em-pe $>\quad$ Access on 21 Aug. 2017.

BROOKS, BRAD. Infrastructure inequality is catalyst for Brazil's Zika epidemic. March 15, 2016. Available at $<$ http://www.reuters.com/article/us-health-zika-inequality-insightidUSKCNOWHOEH> Access on 21 Aug. 2017.

CEDAW. Concluding observations of the Committee on the Elimination of Discrimination against Women. February 23, 2012. Available at: $<$ http://www2.ohchr.org/english/bodies/cedaw/docs/co/CEDAW-C-BRA-CO-7.pdf $>$ Access on 21 Aug. 2017.

CENTER FOR REPRODUCTIVE RIGHTS. KL v. Peru (United Nations Human Rights Committee). Available at: $<$ http://www.reproductiverights.org/case/kl-v-peru-united-nationshuman-rights-committee $>$ Access on 21 Aug. 2017.

CESAR, Juraci A. et al . Assistência pré-natal nos serviços públicos e privados de saúde: estudo transversal de base populacional em Rio Grande, Rio Grande do Sul, Brasil. Cad. Saúde Pública, Rio de Janeiro, v. 28, n.11, p. 2106-2114, Nov. 2012. Available at $<\underline{\text { http://www.scielo.br/scielo.php?script }=\text { sci arttext\&pid }=\text { S0102- }}$

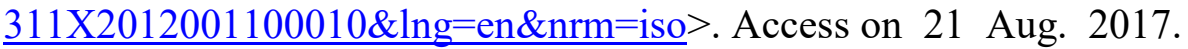

CHAMALLAS, Martha. Introduction to Feminist Legal Theory, New York: Aspen Publishers, 2003.

COLLUCCI, Claudia. 'Melhor prevenção à microcefalia é evitar engravidar', afirma obstetra. December $1, \quad 2015.2$ Available at $<$ http://www1.folha.uol.com.br/cotidiano/2015/12/1713277-melhor-prevencao-amicrocefalia-e-evitar-engravidar-afirma-obstetra.shtml $>$ Access on 21 Aug. 2017. 
COUNCIL OF EUROPE. Convention on preventing and combating violence against women and domestic violence. 2011. Available at: $<$ https://rm.coe.int $/ 168008482 \mathrm{e}>$ Access on 21 Aug. 2017.

DINIZ, Debora; MEDEIROS, Marcelo; MADEIRO, Alberto. Brazilian women avoiding pregnancy during Zika epidemic. Journal of Family Planning \& Reproductive Health Care. 2017.

DUDOVÁ, Radka. The Framing of Abortion in the Czech Republic: How the Continuity of Discourse Prevents Institutional Change. Czech Sociological Review, Vol. 46, No. 6, p. 945 975, 2010.

FAUNDES, Aníbal; CECATTI, José Guilherme. A operação cesárea no Brasil: incidência, tendências, causas, conseqüências e propostas de ação. Cad. Saúde Pública, Rio de Janeiro, v. 7, n. 2, p. 150-173, June $1991 . \quad$ Available at $<$ http://www.scielo.br/scielo.php?script=sci arttext\&pid=S0102-

311X1991000200003\&lng=en\&nrm=iso $>$. Access on 21 Aug. 2017.

FUNDAÇÃO PERSEU ABRAMO. Balanço das políticas de educação em direitos humanos e cidadania, 2016. Available at: $<$ http://www.fpabramo.org.br/publicacoesfpa/wpcontent/uploads/2016/06/fpa-discute-balanco-politicas-1.pdf $>$ Access on 21 Aug. 2016.

GONÇALVES, Tamara Amoroso. Direitos Humanos das Mulheres e a Comissão Interamericana de Direitos Humanos. São Paulo: Editora Saraiva, 2013.

GRUPO DE PESQUISA DIREITOS HUMANOS, PODER JUDICIÁRIO E SOCIEDADE UERJ; IPAS BRASIL. Mulheres incriminadas por aborto no RJ: diagnóstico a partir dos atores do sistema de justiça. Rio de Janeiro, 2012. Available at: $<$ http://www.apublica.org/wp-content/uploads/2013/09/Relatório-FINAL-para-IPAS.pdf $>$.

Access on 21 Aug. 2017.

HABERMAS, Jürgen. The Concept of Human Dignity and the Realistic Utopia of Human Rights. Metaphilosophy, vol. 41, no. 4, July 2010, pp. 464-480.

HTUN, Mala. Sex and the State: Abortion, Divorce and the Family Under Latin American Dictatorships and Democracies. New York: Cambrigde University Press, 2003. 
INSTITUTO PATRÍCIA GALVÃO. Cai número de locais que fazem aborto legalizado. 29

Oct. 2015. Available at $<$ http://agenciapatriciagalvao.org.br/direitos-sexuais-ereprodutivos/cai-numero-de-locais-que-fazem-aborto-legalizado/> Access on 21 Aug. 2017.

JAENISCH, Thomas et al. Risk of microcephaly after Zika vírus infection in Brazil, 2015 to 2016. Bull World Health Organ 2017, n. 95, p. 191-198. Available at: $<$ http://dx.doi.org/10.2471/BLT.16.178608> Access on 21 Aug. 2017.

MACKINNON, Catharine. Rape, Genocide, and Women's Human Rights. In: HAYDEN, Patrick (org.) The Philosophy of Human Rights. St Paul, MN: Paragon House, 2001.

MARCUSE, Herbert. The New Left and the 1960s. New York: Routledge, 2005.

MINISTÉRIO DA SAÚDE. Atenção às mulheres com gestação de anencéfalos: norma técnica. Brasília: Ministério da Saúde, 2014. Available at $<$ http://bvsms.saude.gov.br/bvs/publicacoes/atencao mulheres gestacao anencefalos.pdf $>$ Access on 21 Aug. 2017.

Boletim Epidemiológico, v. 47, n. 37, 2016a. Available at:

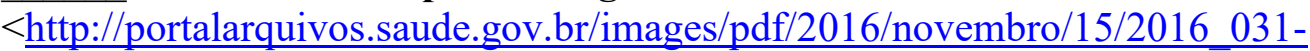
Mulheres publicacao.pdf> Access on 21 Aug. 2017.

Boletim Epidemiológico, v. 48, n. 7, 2017. Available at: $<$ http://portalarquivos.saude.gov.br/images/pdf/2017/marco/14/2017 006-Monitoramentodos-casos-de-dengue-febre-de-chikungunya-e-febre-pelo-virus-Zika-ate-a-SemanaEpidemiologica-7.pdf $>$ Access on 21 Aug. 2017.

Informe Epidemiológico n. 38: Monitoramento da Microcefalia no Brasil. 2016b. Available at: $<\mathrm{http}$ ://combateaedes.saude.gov.br/images/sala-desituacao/informe_microcefalia_epidemiologico38.pdf $>$ Access on 21 Aug. 2017.

Portaria n. 204, de 17 de fevereiro de 2016. Define a Lista Nacional de Notificação Compulsória de doenças, agravos e eventos de saúde pública nos serviços de saúde públicos e privados em todo o território nacional, nos termos do anexo, e dá outras providências. 2016c. Available at: $<\underline{\text { http://pesquisa.in.gov.br/imprensa/jsp/visualiza/index.jsp?jornal }=1 \& \text { pagina }=23 \& d a t a=18 / 02}$ /2016> Access on 21 Aug. 2017. 
MINKKINEN, Panu. "If Taken in Earnest": Criminal Law Doctrine and the Last Restort. The Howard Journal, n. 45, Dec. 2006.

MONTEIRO, Mario Francisco Giani; ADESSE, Leila; DREZETT, Jefferson. Atualização das estimativas da magnitude do aborto induzido, taxas por mil mulheres e razões por 100 nascimentos vivos do aborto induzido por faixa etária e grandes regiões. Brasil, 1995 a 2013. Reprodução \& Climatério, vol. 30, n. 1, p, 11-18, 2015. Available at: $<$ http://recli.elsevier.es/pt/atualizacao-das-estimativas-damagnitude/articulo/S1413208715000254/> Access on 21 Aug. 2017.

PASINATO, Wânia. Dez anos de Lei Maria da Penha: O que queremos comemorar? SUR, n. 24 , v. 13, 2016, p. 155-163. Available at $<\underline{\mathrm{http}: / / \text { sur.conectas.org/wp- }}$ content/uploads/2017/02/14-sur-24-por-wania-pasinato.pdf $>$ Access on 21 Aug. 2017.

PETERSON, Lyle R. et al. Zika Virus. The New England Journal of Medicine, n. 374, p. 1552-1563, 2016. Available at $<$ http://www.nejm.org/doi/full/10.1056/NEJMra1602113 -

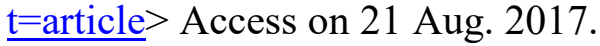

PIOVESAN, Flavia. Direitos Humanos e o Direito Constitucional Internacional. São Paulo: Editora Saraiva, 2006.

Direitos Sexuais e Reprodutivos: Aborto inseguro como violação aos direitos humanos. In: SARMENTO, Daniel (org.). Nos limites da vida: aborto, clonagem humana e eutanásia sob a perspectiva dos direitos humanos. Rio de Janeiro: Lumen Juris, 2007.

ROSENDO, Daniela; GONÇALVES, Tamara Amoroso. Direito à vida e a personalidade do feto, aborto e religião no contexto brasileiro: Mulheres entre a vida e a morte. ethic@ - An international Journal for Moral Philosophy, Florianópolis, v. 14, n. 2, p. 300-319, jan. 2016. Available at: $<$ https://periodicos.ufsc.br/index.php/ethic/article/view/37648>. Access on 21 Aug. 2017.

ROSENDO, Daniela. Sensível ao cuidado: Uma perspectiva ética ecofeminista. Curitiba: Editora Prismas, 2015.

RUIBAL, Alba M.. Feminismo frente a fundamentalismos religiosos: mobilização e contramobilização em torno dos direitos reprodutivos na América Latina. Rev. Bras. Ciênc. Polít., Brasília, n. 14, p. 111-138, Aug. 2014. Available at $<$ http://www.scielo.br/scielo.php?script=sci arttext\&pid=S0103-

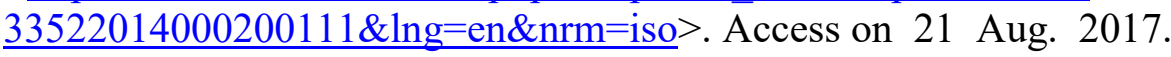


SENICATO, Caroline; BARROS, Marilisa Berti de Azevedo. Social inequality in health among women in Campinas, São Paulo State, Brazil. Cad. Saúde Pública, Rio de Janeiro, v. 28, n. 10, p. 1903-1914, Oct. 2012. Available at $<$ http://www.scielo.br/scielo.php?script $=$ sci arttext\&pid $=$ S0102-

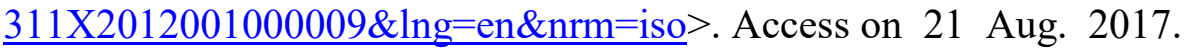

SENRA, Ricardo. Grupo prepara ação no STF por aborto em casos de microcefalia. 29 Jan. 2016, Available at $<$ http://www.bbc.com/portuguese/noticias/2016/01/160126_zika_stf_pai_rs $>$ Access on 21 Aug. 2017.

SOUZA, Jessé de. A ralé brasileira: Quem é e como vive. Belo Horizonte: Ed. UFMG, 2016.

THE LANCET. Another kind of Zika public health emergency. v. 389, Feb. 112017. Available at: $\quad<$ http://www.thelancet.com/pdfs/journals/lancet/PIIS0140-6736(17)303252.pdf> Access on 21 Aug. 2017.

TIBURI, Márcia. Aborto como metáfora. In: BORGES, Maria de Lourdes; TIBURI, Márcia (Org.). Filosofia: machismos e feminismos. Florianópolis: Ed. da UFSC, 2014, p. 163-176.

TRETTEL, Daniela Batalha. Planos de saúde na Justiça: o direito à saúde está sendo efetivado?. 2009. Dissertação (Mestrado em Diretos Humanos) - Faculdade de Direito, Universidade de São Paulo, São Paulo, 2009.

UNITED NATIONS. Upholding women's human rights essential to Zika response. 2016. Available at: $<$ http://www.ohchr.org/EN/NewsEvents/Pages/DisplayNews.aspx?NewsID=17014 $>$ Access on 21 Aug. 2017.

VIELLAS, Elaine Fernandes et al . Assistência pré-natal no Brasil. Cad. Saúde Pública, Rio de Janeiro, v. 30, supl. 1,p. S85-S100, 2014. Available at $<$ http://www.scielo.br/scielo.php?script=sci arttext\&pid=S0102-

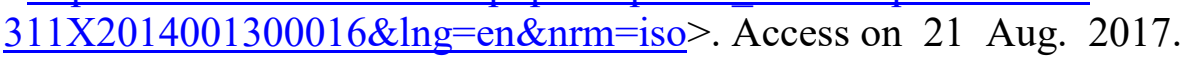

WENTZEL, Marina. Médico ligado à OMS recomenda que mulheres em área de surto de Zika evitem engravidar. 04 Dec. 2015, Available at $<$ http://g1.globo.com/bemestar/noticia/2015/12/medico-da-oms-recomenda-que-mulheres-emarea-com-surto-de-zika-evitem-engravidar.html > Access on 21 Aug. 2017. 
WHO. Fifth meeting of the Emergency Committee under the International Health Regulations (2005) regarding microcephaly, other neurological disorders and Zika virus. Nov. $\quad$ 18, 2016. Available at:

http://www.who.int/mediacentre/news/statements/2016/zika-fifth-ec/en/> Access on 21 Aug. 2017.

- Situation report: Zika Virus, Microcephaly, Guillain-Barré Syndrome. Mar. 10, 2017. Available at:

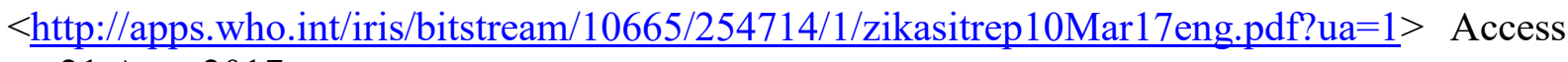
on 21 Aug. 2017. 